\title{
Effect of Naphthalene Acetic Acid on Growth and Yield of Radish (Raphanus sativus L.)
}

\author{
Amit Sharma* and Vijay Bahadur \\ Department of Horticulture (Naini Agricultural institute), SHUATS, Prayagraj, India \\ *Corresponding author
}

\section{A B S T R A C T}

Keywords

NAA,

Concentration, Radish, Pusa Desi, Pusa Himani, Pusa chetki

Article Info

Accepted:

20 December 2020

Available Online:

10 January 2021
The experiment was carried out in vegetable Research Farm Department of Horticulture College of Agriculture, Allahabad Agricultural Institute, Sam Higginbottom institute of Agriculture, Technology and sciences, Deemed-to-be university Allahabad (U.P.) during Rabi 2008 to evaluate the effect of Naphthalene Acetic Acid on Growth and Yield of Radish (Raphanus sativus L.). The treatment consisted of three radish varieties i.e., Pusa Desi, Pusa Himani \& Pusa Chetki with four concentrations of NAA viz., 0 ppm, 25 ppm, $50 \mathrm{ppm}$ and $75 \mathrm{ppm}$. Thus 12 treatments combination were replicated three times in factorial randomized block design. The interaction between varieties and NAA concentration significantly influenced the number of leaves per plant, length of root per plant and leaf and root weight per plant. Therefore, the maximum number of leaves, length of roots, leaves, root weight and yield (490.73 q/ha) were found in Pusa Himani with 50 ppm NAA combination. The net return and benefit cost ratio was recorded up to Rs. 2373/ha and 1.92 , respectively.

\section{Introduction}

Radish is an annual herb hairy of thickened and tuberous roots, externally white or red round cylindrical or tapering, internal tissue is white. Radish leaves are lyrate-pinnatified up to $25 \mathrm{~cm}$ in length with large terminal lobe (Tindall, 1983). Radish (Raphanus sativus) is a native of Europe or Asia and was being used by Egyptian at the time of Pharaohs (Splittstoesser, 1984). Peirce (1987) reported that, radish cultivars may be grouped according to season (summer, winter and all season) and with each season by shape and colour. Several cultivars of summer type are available with resistance or tolerance to club roots (Saxafire, Novitas) and the globe shape desired by consumers. Winter radish is the most successfully grown as a fall crop when short days and a cool temperature minimize bolting. Field uniformity and radish stands are of high significance in mass production, and therefore workers pay intensive care to theses factors. Gray et al., (1985) found that within root crop species, there is typically a two fold variation in seed or fruit weigh. In Brassica root crops, variation in seed and embryo are closely related, because the embryonic mass is a large part of the seed structure. Benjamin (1990) found that variation in seedling size or 
mass at emergence can arise from variation is seed weight, embryonic weight, duration of pre-emergence growth and pre-emergence growth rates. Gray et al., (1991) found that, in beet and root Brassicas there are detailed relationships between seed and embryo weights have not established. Manipulating in plating dates to synchronize growth stages each with its favourable growth temperature is also of high benefit. Das Gupta (1972) applied different temperature 15 to $250 \mathrm{C}$ to sugar beet, but in all treatment the shoot apical meristem was removed. This had three effects. First, that any signal that might be produced by this meristem was removed. Second, the sink activity would occur as some remaining leaves continued to grow. Third, the high temperature promoted senescence, which could not compensated for by the growth of new leaves, allowing for the more rapid leaf senescence at higher temperature. Radishes are easy and quick to grow, cool weather is essential for highest radish quality, since they become hot and woody in hot weather, small round varieties mature more quickly than long type (Jones, et al., 2003). The objective of this study is to improve yield and yield quality of well irrigated radish by the aid of naphthalene acetic acid. Many vegetables are grown mainly near the urban centers in the country (Bakhsh et al., 2006). This is a profitable business because of local consumption and marketing as well as export for earning income (Tunio and Majeedano, 2001). Statistics indicate that Sheikhupura, Sahiwal, Kasur, Toba Tek Singh, Rahim Yar Khan and Okara are major vegetable growing districts in Punjab but production trends fluctuate in response to prices in the market (Bakhsh et al., 2006). Vegetable crops are very important due to their higher yield potential, low cost of production and higher nutritional value. Vegetables are comparatively rich source of vitamins and minerals, which are essential for the maintenance of good health and resistance against diseases. Besides providing crucial dietary nutrients, vegetables generate far higher income than the staple food and cash crops such as wheat and cotton. Moreover, they help to improve the productivity and sustainability of the cereal-based production system (Ali and Abedullah, 2002). Being the labour intensive crops, vegetable cultivation generates higher employment opportunities at the farm level than cereals (Abedullah et al., 2002). The cultivation of vegetables at commercial level has been relatively unsatisfactory due to ignorance of these crops in research and extension policies. This results in relatively smaller percentage of cropped area under vegetable cultivation (Ahmad et al., 2003). The per capita per day consumption of vegetable in Pakistan is almost half of the recommended level of $200 \mathrm{~g}$ per person per day (Farooq and Ali, 2002). Most commonly grown vegetables include potato, onion, tomato, chilli, gourds and melons etc. Among winter vegetables radish is highly profitable crop which can be grown in almost every season on all types of soils but spreads well in light, nutrient rich and moist soils in shorter plantation time. According to an estimate, total vegetable area and production of radish in Pakistan has seen increasing trend during 2002-03 and 2011-12 from 520.9 to 611.7 thousand ha and production from 6454.2 to 8478.8 thousand tonnes, respectively. Punjab province has comparatively higher share in area (60\%) and production of vegetables $(67 \%)$ including potato and condiments. Radish yield at farm level -1 (16.2 $\mathrm{t} \mathrm{ha}$ ) is much less as compared to that at experimental stations (30 t-1 ha) which results in almost $46 \%$ yield gap (GoP, 2012). Policy makers and planners primarily always need information on essential cereal crops, but now-adays due to persistent price hikes especially in the vegetables, policy makers and planners have started giving importance to the vegetables. This needs latest information on vegetable production 
and marketing statistics. Economic analysis of vegetables has been conducted by st many researchers over the 1 decade st of 21 century (Ahmad et al., 2004; Bakhsh and Hassan et $a l ., 2005)$ following objectives to find out the suitable variety of radis in Allaabad (U.P).to evaluate the optimum concentration of Naphthalene acitic acid.to find out the suitable combination of variety and concentration of naphthalene acetic acid for growth and yield attributes of radish.

\section{Materials and Methods}

The field experiment was conducted at the Vegetable research Farm, Department of Horticulture College of Agriculture, Allahabad Agricultural Institute, Sam Higginbottom institute of Agriculture, Technology and sciences, Deemed-to-be university Allahabad (U.P.) during Rabi 2008 situated in the eastern part of Uttar Pradesh near river of Yamuna. The climate of this region is semi-arid and subtropical having extreme winter and summer. The temperature varies from maximum of $45.6^{\circ} \mathrm{C}$ to a minimum of $1.1^{0} \mathrm{C}$ also situated at the latitude of $25.25 \mathrm{~N}$, longitude $81.58 \mathrm{E}$ and altitude $98 \mathrm{~m} / 340 \mathrm{ft}$ above the sea level. The weather as observed during experimental time cool winter followed by warm spring. The experimental field was laid out randomized block design (Factorial) with three replications. Each replication consisted of 12 treatments. Varieties of radish Pusa desi, Pusa Himani, Pusa Chetaki and contration of Naphthalene acetic acid 0 PPM (Control) 25 PPM, 50 PPM and 75 PPM. NAA solution of 25,50 and $75 \mathrm{ppm}$ were prepared through stock solution. For stock solution of respective plant growth substance, $100 \mathrm{mg}$ NAA was dissolved in reqired quantity of 95\% ethyl alcohol and volume was made up to mark with distilled water in $100 \mathrm{ml}$ measuring flask. $\mathrm{pH}$ of the NAA solution was tested by $\mathrm{pH}$ meter to maintain the normally $(7.5 \mathrm{pH})$ of the solution and for 25,50 and 75 ppm hormonozed solution, $1000 \mathrm{ml}$ of distilled water was measured and put into the beakers and than after 25,0 and $75 \mathrm{ml}$ water stock solution were taken in separate beaker with the help of a pipette. This was added slowly in distilled water, more alcohol was taken in beaker to rinse it. The rinset was also added to the solution to maintain the accuracy solution of each concentration of NAA separately and for control in distilled water for 24 hours and then after seed of every variety were taken out from the solution dried in shady place for 2 hours and in this way harmonized seed were kept for sowing purpose.

\section{Results and Discussion}

The maximum height (55.63) $\mathrm{cm}$ was recorded under variety Pusa Chetki and was significantly higher to Pusa Desi and Pusa Himani, this was, however, followed by Pusa Desi, and then the lowest height $(51.74 \mathrm{~cm})$ was observed with the application of $60 \mathrm{ppm}$ and minimum height with control treatment. The interaction effect between varieties and concentrations of NAA was found to be significant. The maximum height $(57.80 \mathrm{~cm})$ was recorded under Pusa Chetki with 60ppm NAA treatment combination. The perusal of above table showed that the maximum average number of leaves per plant (18.01) was recorded for variety Pusa Himani and was statically superior to other two varieties (16.42 to 16.62 leaves/plant). The number of leaves per plant increased significantly with the application of NAA. The maximum number of leaves (17.74) was control under treatment $75 \mathrm{ppm}$ NAA as against minimum (16.26) in the control treatment. However, 50ppm NAA was observed to be significantly 0073uperior over control. Only 75 ppm NAA was found significantly superior to 0 and 25 ppm NAA. The similar result trend was noticed at the final stage (40 DAS). The analysed data indicated that the average 
length of leaves not only varying from variety to variety but also was affected by different concentration of NAA. The maximum length $(55.25 \mathrm{~cm})$ of leaf was Noticed in case of Pusa Chetki being significantly superior only Pusa Desi $(42.45 \mathrm{~cm})$. The application of different concentration of NAA showed significant effect on the length of leaves of radish. The maximum length of leaf $51.75 \mathrm{~cm}$ was measured in case of 50 ppm NAA. Closely followed by $75 \mathrm{ppm}$ NAA at 40 days after sowing. The lowest length $(49.40 \mathrm{~cm})$ was noted in case of zero concentration of NAA. The interaction between concentration of NAA and the varieties was found to significant at final stage also. Thus, the maximum length of leaf $(57.80 \mathrm{~cm})$ was measured under treatment combination of Pusa Chetki with 50ppm NAA (table 4.3.1.). This was followed by the same variety with $75 \mathrm{ppm}$ NAA $(57.23 \mathrm{~cm})$.

The similar result trend was observed at the final stage. The width of leaf was significantly affected due to varieties and NAA concentration. The width of leaves under variety Pusa Desi was found to be maximum $(15.92 \mathrm{~cm})$ as against minimum $(14.19 \mathrm{~cm} 0$ in Pusa Himani. Pusa Desi variety was significantly superior to the meaning two varieties $(14.19$ to $14.76 \mathrm{~cm})$. There was significant improvement of leaves with the application of NAA. The significantly maximum width $(15.25 \mathrm{~cm})$ of leaf was recorded under the 50ppm NAA. Whereas the minimum $(14.61 \mathrm{~cm})$ in control. The 25 and $75 \mathrm{ppm}$, concentration were found identical but significantly superior to zero concentration of NAA. The effect of interaction between varieties and NAA concentration was found to be significantly. Thus, the maximum width $(16.30 \mathrm{~cm})$ was recorded under the treatment combination of Pusa Desi with 50 ppm concentration NAA. It is obvious from the table 4.5 that the fresh weight of leaves per plant was found to vary significantly due to treatments and their interactions. The maximum fresh weight of leaves $(227.66 \mathrm{~g})$ was produce by variety Pusa Himani which was significantly higher to other varieties Pusa Desi was significantly higher in fresh weight as compared to Pusa Chetki. The variety Pusa Chetki. Produced minimum fresh weight of leaves (202.75g). The application of different concentrations of NAA had significant effect on the fresh weight of leaves. The significantly maximum weight of leaves $(225.44 \mathrm{~g})$ was observed in case of 50ppm. Concentration of NAA over all the other concentrations. The minimum (201.44g) was noted in the control treatment. The variety Pusa Chetki produced the significantly minimum $(4.90 \mathrm{~cm})$ girth of root as other varieties. However, the minimum girth of root $(3.12 \mathrm{~cm})$ was recorded for variety Pusa Desi. The girth of roots increased significantly with the application of NAA. The significantly higher girth of root $(5.48 \mathrm{~cm})$ was observed from $75 \mathrm{ppm}$ NAA as compare to other concentrations. The lowest girth of root $(2.64 \mathrm{~cm})$ was noted at zero concentration of NAA.

The interaction between varieties and concentration of NAA was also found to be significant. Accordingly, the significantly maximum girth of root $(10.10 \mathrm{~cm})$ was observed in case of Pusa Chetki with $75 \mathrm{ppm}$ NAA combination. This was significantly higher to all the rest of the interaction. On the other hand, the minimum girth $(2.33 \mathrm{~cm})$ was recorded in case of Pusa Desi without NAA. The perusal of the data in table 4.8 indicated that the highest weight of root $(146.89 \mathrm{~g})$ was recorded from variety Pusa Himani, being significantly higher and higher to Pusa Desi (137.97g) and Pusa Himani (124.59g). Pusa Himani and Pusa Chetki responded to increase the weight of root per plant significantly with the application of even 25 ppm of NAA as compared to control (no application). Pusa Chetki without NAA 
recorded the minimum fresh weight (11.27)g. The best NAA concentration was $50 \mathrm{ppm}$ which brought about highest net profit up to Rs. 21,669/ ha with benefit cost ratio up to 1.84. Amongst the interactions Pusa Himani with 50 ppm NAA further raised to net profit being Rs. 23,473 / ha and the maximum benefit cost ratio up to 1.92 .

From the present investigation it could be concluded that the radish cultivar Pusa Himani with the seeds treated with NAA @ 50 before sowing exhibited maximum yield (490.73 q/ha) as well as net profit (Rs. $23,473 /$ ha). Since these findings are based on one year observations therefore, research may be repeated to substantiate the findings.

\section{Acknowledgement}

The author are thankful to the Hon'ble Vice Chancellor, HOD, Advisor and Non- teaching staff Department of Horticulture, SHIATS Allahabad, U.P., for providing all necessary facilities and support.

\section{References}

Abedullah, S., Sakham and U.Farooq. 2002. Cambodia. In: Ali,M. (ed.) The Vegetable Sector in Indochina Countries: Farm and household perspective on poverty alleviation. Chapter 2. Asian Vegetable Research and Development Center (AVRDC), Taiwan - Asian Regional Center (ARC), Thailand. Technical Bulletin No. 27: 3173.

Ahmad, B., K. Bakhsh and S. Hassan.2004. Economics of growing different summer vegetables. Faculty of Agricultural Economics and Rural Sociology, University of Agriculture, Faisalabad.

Ahmad, B., K. Bakhsh, S. Hassan and S.B. Khokhar. 2003. Economics of growing different summer vegetables. Faculty of Agricultural Economics and Rural Sociology, University of Agriculture, Faisalabad.

Ali, M. and S. Abedullah. 2002. Nutritional and economic benefits of enhanced vegetable production and consumption. J. Crop Prod. 6: 145-176.

Bakhsh, K., B. Ahmad, Z.A. Gill, S. Hassan and S.A. Adil. 2006. Determinant of radish yield: A case study of Punjab, $J$. Agric. Sci. 43(3-4): 206-208.

Bakhsh, K. and S. Hassan. 2005. Use of sewage water for radish cultivation: A case study of Punjab, J. Agric. Social Sci. 4: 322-326.

Farooq, U. and M. Ali. 2002. Combating micronutrient deficiency in Pakistan by increased vegetable use, Asian Vegetable Research and Development Center (AVRDC), Shanhua, Tainan, Taiwan.

GoP. 2012. Fruit, Vegetables and Condiment Statistics of Pakistan, Ministry of National Food Security and Research, Government of Pakistan, Islamabad.

Hassan, I., K. Bakhsh, M.H. Salik, M. Khalid and N.Ahmad. 2005. Profitability of winter vegetables in Faisalabad (Pakistan). International J. Agric. and Biol. 2:321-322.

Kushk, A.M. and S. Hisbani. 2003. Economic analysis of radish cultivation in sultanabad area in Sindh. Pakistan Journal of Applied Sciences. 3(5):331340.

Muuttama, E. 2000. Finish cucumber even in winter time. Teho, 2:30-31.

Tunio, S. and H.I. Majeedano. 2001. Dynamics of vegetable seed production in Pakistan. Industry \& Economy, May 7-13.Vegetable Research Institute. 2011Production Technology. 


\section{How to cite this article:}

Amit Sharma and Vijay Bahadur. 2021. Effect of Naphthalene Acetic Acid on Growth and Yield of Radish (Raphanus sativus L.). Int.J.Curr.Microbiol.App.Sci. 10(01): 3496-3501. doi: https://doi.org/10.20546/ijcmas.2021.1001.412 